\title{
EFFECT OF SOME ORGANIC COMPOUNDS ON EGYPTIAN COTTON PRODUCTIVITY
}

\author{
Y. F. A. Ata Allah and Amany A. EL-Ashmouny \\ Cotton Physiology Department, Cotton Research Institute, Agriculture Research Center, \\ Giza, Egypt. \\ Received: Jul. 14, $2019 \quad$ Accepted: Aug. 20, 2019
}

ABSTRACT: Two field experiments were conducted on a clay soil at El-Gemmeiza Agricultural Research Station, El-Gharbia Governorate, Egypt during 2016 and 2017 seasons, to study the effect of foliar spraying with three organic acids (propionic, citric and ascorbic acids) and potassium citrate in mixture (two portions potassium citrate, one portion propionic acid, one portion citric acid and one portion ascorbic acids), where three rates of the mixture $(4,8$ and $10 \mathrm{~g} / \mathrm{L}$ ) were foliar spraying two times (at start of flowering and top of flowering) and three times (during squaring stage, start of flowering and top of flowering) in compared to control (untreated plants) on cotton growth, earliness traits, seed cotton yield and its components of Giza 86 cotton cultivar. The experimental design was a randomized complete block design with four replicates.

The important results could be summarized as follows:

Untreated plants and plants which received $4 g$ of the mixture/l twice gave the tallest plants with higher number of fruiting branches in both seasons, while the shortest plants were obtained from plants received $10 \mathrm{~g}$ of the mixture/l three times or two times in the first and second seasons, respectively, with lower number of fruiting branches.

Number of total bolls/plant and boll setting percentage significantly responded to concentrations and number of applications in favor of foliar spraying with $4 \mathrm{~g}$ of the mixture $/ L$ three times. However, the control (untreated plants) produced the lowest values of these traits and the highest values of shedding\% in both seasons.

The tested treatments gave significant effect on number of open bolls/plant, boll weight, seed index, lint $\%$ and seed cotton yield per feddan in both seasons, where the superiority was found in favor of foliar spraying with 4 and 8 g/l three times (during squaring stage, start of flowering and top of flowering) as compared to the other treatments.

Key words: cotton - propionic, citric, ascorbic acid - potassium citrate - flowering and yield.

\section{INTRODUCTION}

The importance of $K_{2}$ fertilization in Egyptian agriculture has become more apparent since the establishment of the High Dam, which resulted in the deposition of the suspended Nile silt upstream from the formed lake. This Nile silt was a source of $K$ bearing minerals that enriched the soils during the seasonal floods. Potassium is a part of many important regulatory roles in the plant. It is essential in nearly all processes needed to sustain plant growth and reproduction, i.e. photosynthesis, translocation of photosynthesis products, protein synthesis, control of ionic balance, regulation of plant stomata, turgor maintenance, stress tolerance and water use, activation enzymes and many other processes (Cakmak, 2005) Potassium deficiencies can limit the accumulation of 
crop biomass. This has been attributed to a reduction in the partitioning of assimilates to the formation of leaf area and $a$ decrease in the efficient use of intercepted radiation for the production of above-ground biomass. Potassium citrate is potassium salt of citric acid which considered one of the most important organic acids in the respiratory pathways into plant cell (lbrahim et al.,2015). Additionally, citric acid plays an important role in plant metabolism, it's as non-enzymatic antioxidant in chelating free radicals and protecting plant from injury could result in prolonging the shelf life of plant cells and improving growth characters (Sadak and Orabi, 2015 and Wang et al., 2013). Potassium is a major plant nutrient, which is essential for a variety of physiological processes i.e. photosynthesis, protein synthesis, enzyme activation and maintenance of water status in plant tissues (Marschner, 2012).

Citric Acid is an organic compound belonging to the family of carboxylic acids. It presents in practically all plants. It is one of a series of compounds involved in the physiological oxidation of fats, proteins and carbohydrates to $\mathrm{CO}^{2}$ and water. Many researchers' works on effects of citric acid on growth and yield of crops. In this respect, Abd-Allah et al. (2007) indicated that plant height, yield and its components as well as protein content in common bean, pea and faba bean were increased with application of citric acid. Sheteawi (2007) stated that ascorbic and citric acids appeared to act in a concert which indicates a complete set of antioxidant defense system, rather than protection by a single antioxidant under stressful conditions.

Ascorbic acid serves as a co-factor for many enzymes and contributes to the detoxification of ROS (Conklin and Barth
2004). The antioxidant activity of Ascorbic acid is associated with longevity in plants and resistance to oxidative stress. Further, the endogenous level of Ascorbic acid is suggested to be important in the regulation of developmental senescence (Pavet et al. 2005). Ascorbic acid (vitamin $\mathrm{C}$ ) has a regulatory role in promoting productivity in many plants, Ascorbic acid acts as a cofactor for several enzymes and regulates the phytohormone-mediating signaling processes [Barth and Mario (2006)] and many physiological processes in plants [Farooq et al. (2013)]. Ascorbic acid is cofactors for enzyme activity, and effects on plant antioxidation capacity, heavy metal evacuation and detoxification and stress defense, Zhang (2012). Khan et al. (2011) stated that ascorbic acid currently holds a significant position in plant physiology, mainly due to its possession of antioxidant and cellular reductant etc. properties and its diverse roles in plant growth and development and the regulation of a broad spectrum of plant cellular mechanisms against environmental stresses. Ascorbate is a major metabolite in plants performing a key role in plant protection against numerous environmental stresses like high temperature, salinity etc. (Vwioko et al., 2008). Ascorbic acid is used as an indication compound in many studies which are related with alleviation of stress (Lopez et al., 2011). Ascorbic acid is regarded as one of the most effective growth regulators in different abiotic stresses (Conklin, 2001).

Propionic or propionic acid (CH3-CH2COO-) is a weak monocarboxylic acid and an intermediate or end product of carbon metabolic pathways in pro- and eukaryotes (Schneider et al., 2011). Propionic acid is the second most abundant organic acid in soil (Conrad 
and Klose, 1999), therefore roots are constantly exposed to propionate and exogenous propionate naturally influences plant metabolism in the root. Propionic acid $\left(\mathrm{CH}_{3}-\mathrm{CH}_{2}-\mathrm{COOH}\right)$ is substances referred to collectively as the Carboxylic Acids Group and is registered pesticide formulants. Propionic acid is listed in the Natural Health Products Ingredients Database (NHPID) with a medicinal role and classified as a natural health product (NHP) substance.

\section{MATERIALS AND METHODES}

Two field experiments were conducted on a clay soil at El-Gemmeiza Agricultural Research Station, El-Gharbia Governorate, Egypt during 2016 and 2017 seasons, to study the effect of foliar spraying with three organic acids (propionic, citric and ascorbic acids) and potassium citrate as anti-transpiration in mixture (two portions potassium citrate, one portion propionic acid, one portion citric acid and one portion ascorbic acids), where three rates of the mixture of four anti respirators $(4,8$ and $10 \mathrm{~g} / \mathrm{L})$ were foliar spraying two times ( at start of flowering and top of flowering) and three times (during squaring stage, start of flowering and top of flowering) in compared to control (untreated plants) on cotton growth, earliness traits, seed cotton yield and its components of Giza 86 cotton cultivar. The experimental design was a randomized complete block design with four replicates.

Representative soil samples were taken from the experimental soil sites before sowing in both seasons and prepared for analysis according to Jackson (1973). Results of the soil analysis are shown in Table 1.

Table 2 shows data of air temperature and relative humidity which obtained from the Department of Meteorology, Agricultural Research Center.

Table 1: Properties of the experimental soil sites in the two seasons of study.

\begin{tabular}{|l|c|c|}
\hline \multirow{2}{*}{\multicolumn{1}{|c|}{ Properties }} & \multicolumn{2}{c|}{ Season } \\
\cline { 2 - 3 } & 2016 & 2017 \\
\hline $\mathrm{pH}$ & 7.8 & 8.0 \\
\hline Texture class & Clay & Clay \\
\hline EC m mhos/ cm. & 0.56 & 0.54 \\
\hline Organic matter \% & 1.29 & 1.42 \\
\hline Total N (mg/100g) & 45.15 & 49.7 \\
\hline Available N (ppm) & 21.3 & 28.7 \\
\hline Available P (ppm) & 10.7 & 11.1 \\
\hline Exchangeable K (ppm) & 312 & 306 \\
\hline Available Fe (ppm) & 10.6 & 11.0 \\
\hline Available Mn (ppm) & 3.8 & 2.9 \\
\hline Available Zn (ppm) & 1.1 & 0.90 \\
\hline Available Cu (ppm) & 3.22 & 3.0 \\
\hline
\end{tabular}


Y. F. A. Ata Allah and Amany A. EL-Ashmouny

Table 2: Minimum, maximum and mean values of air temperature and the relative humidity as means of seven-day intervals through 2016 and 2017 seasons

\begin{tabular}{|c|c|c|c|c|c|c|c|c|c|}
\hline & \multirow{3}{*}{ Intervals } & \multicolumn{4}{|c|}{2016 season } & \multicolumn{4}{|c|}{2017 season } \\
\hline & & \multicolumn{3}{|c|}{$\begin{array}{l}\text { Air temperature } \\
\left({ }^{\circ} \mathrm{C}\right)\end{array}$} & \multirow{2}{*}{$\begin{array}{c}\text { Relative } \\
\text { Humidity } \\
\%\end{array}$} & \multicolumn{3}{|c|}{$\begin{array}{l}\text { Air temperature } \\
\qquad\left({ }^{\circ} \mathrm{C}\right)\end{array}$} & \multirow{2}{*}{$\begin{array}{c}\text { Relative } \\
\text { Humidity } \\
\%\end{array}$} \\
\hline & & Min. & Max. & Mean & & Min. & Max. & Mean & \\
\hline \multirow{3}{*}{ 등 } & $2^{\text {nd }}$ week & 10.7 & 24.6 & 17.65 & 45.8 & 12.5 & 27.8 & 20.15 & 73.3 \\
\hline & $3^{r d}$ week & 11.0 & 29.0 & 20.00 & 37.8 & 13.0 & 32.0 & 22.50 & 69.0 \\
\hline & $4^{\text {th }}$ week & 11.7 & 29.9 & 20.80 & 36.3 & 13.5 & 32.5 & 23.00 & 62.0 \\
\hline \multirow{4}{*}{ 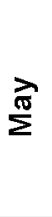 } & $1^{\text {st }}$ week & 13.0 & 31.1 & 22.05 & 41.3 & 14.1 & 30.1 & 22.10 & 64.4 \\
\hline & $2^{\text {nd }}$ week & 16.9 & 32.5 & 24.70 & 38.0 & 16.2 & 33.6 & 24.90 & 56.4 \\
\hline & $3^{r d}$ week & 16.4 & 35.5 & 25.95 & 34.5 & 17.2 & 31.9 & 24.55 & 61.5 \\
\hline & $4^{\text {th }}$ week & 20.8 & 38.4 & 29.60 & 27.7 & 16.0 & 30.4 & 23.20 & 61.8 \\
\hline \multirow{4}{*}{$\stackrel{9}{5}$} & $1^{\text {st }}$ week & 17.5 & 33.7 & 25.60 & 39.6 & 19.6 & 37.5 & 28.55 & 54.5 \\
\hline & $2^{\text {nd }}$ week & 19.2 & 35.4 & 27.30 & 41.9 & 19.5 & 32.5 & 26.00 & 65.5 \\
\hline & $3^{r d}$ week & 19.6 & 36.9 & 28.25 & 38.8 & 19.7 & 33.9 & 26.80 & 69.8 \\
\hline & $4^{\text {th }}$ week & 19.2 & 35.5 & 27.35 & 41.2 & 22.7 & 34.7 & 28.70 & 79.0 \\
\hline \multirow{4}{*}{$\frac{\pi}{3}$} & $1^{\text {st }}$ week & 19.3 & 36.0 & 27.65 & 42.2 & 22.4 & 32.8 & 27.60 & 82.0 \\
\hline & $2^{\text {nd }}$ week & 20.6 & 37.2 & 28.90 & 40.3 & 21.0 & 34.0 & 27.50 & 77.4 \\
\hline & $3^{r d}$ week & 21.2 & 38.7 & 29.95 & 35.4 & 20.1 & 33.1 & 26.60 & 77.2 \\
\hline & $4^{\text {th }}$ week & 22.2 & 39.6 & 30.90 & 33.0 & 20.8 & 32.9 & 26.85 & 81.8 \\
\hline \multirow{4}{*}{ 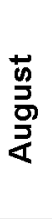 } & $1^{\text {st }}$ week & 24.5 & 41.2 & 32.85 & 37.3 & 21.7 & 37.2 & 29.45 & 81.9 \\
\hline & $2^{\text {nd }}$ week & 25.0 & 40.6 & 32.80 & 37.6 & 21.4 & 39.4 & $r \cdot .40$ & 82.5 \\
\hline & $3^{\text {rd }}$ week & 24.2 & 40.3 & 32.25 & 41.2 & 19.6 & 38.1 & $2 \wedge . \wedge 5$ & 79.0 \\
\hline & $4^{\text {th }}$ week & 22.4 & 37.5 & 29.95 & 45.7 & 21.7 & 38.7 & $r_{\cdot}, r_{.}$ & 81.1 \\
\hline \multirow{4}{*}{ 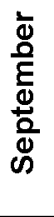 } & $1^{\text {st }}$ week & 20.8 & 37.4 & 29.10 & 44.7 & 19.5 & 39.8 & 29.75 & 78.8 \\
\hline & $2^{\text {nd }}$ week & 22.4 & 39.6 & 31.00 & 46.2 & 17.0 & 40.6 & $2 \wedge .80$ & 78.6 \\
\hline & $3^{\text {rd }}$ week & 22.5 & 36.7 & 29.60 & 43.3 & 15.0 & 38.0 & 27.50 & 76.3 \\
\hline & $4^{\text {th }}$ week & 23.0 & 37.0 & 30.00 & 42.0 & 14.8 & 38.5 & 27.65 & 74.7 \\
\hline \multirow{4}{*}{ 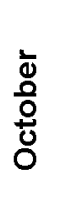 } & $1^{\text {st }}$ week & 20.2 & 32.9 & 26.55 & 53.5 & 14.0 & 29.0 & 21.50 & 78.2 \\
\hline & $2^{\text {nd }}$ week & 19.9 & 33.3 & 26.60 & 55.4 & 14.0 & 30.0 & 22.00 & 76.5 \\
\hline & $3^{r d}$ week & 18.9 & 32.2 & 25.55 & 56.3 & 13.0 & 28.0 & 20.50 & 77.3 \\
\hline & $4^{\text {th }}$ week & 19.4 & 30.6 & 25.00 & 53.1 & 13.0 & 28.0 & 20.50 & 76.9 \\
\hline
\end{tabular}

The experimental plot size was 14 $\mathrm{m}^{2},(4 \mathrm{~m} \times 3.5 \mathrm{~m})$ including 5 rows 70 $\mathrm{cm}$ apart and the hills $25 \mathrm{~cm}$. apart with two plants / hill after thinning in both seasons. Planting date was on $8^{\text {th }}$ April in the two seasons. 
The preceding crop was Egyptian clover (Trifolium alexandrinum L.) "Berseem" in both seasons.

Phosphorus fertilizer was added as calcium super phosphate $\left(15.5 \% \mathrm{P}_{2} \mathrm{O}_{5}\right)$ at a rate of $22.5 \mathrm{~kg} \mathrm{P}_{2} \mathrm{O}_{5} /$ fed during land preparation. Nitrogen fertilizer was applied as Urea $(46 \% \mathrm{~N})$ at a rate of $60 \mathrm{~kg}$ $\mathrm{N} /$ fed was applied in two equal doses, immediately before the first and the second irrigation to produced excessive vegetative growth in cotton. Potassium fertilizer in the form of potassium sulphate was applied as foliar application three times at the rate of $50 \mathrm{~kg} / \mathrm{fed}$.

The other cultural practices were carried out as recommended for conventional cotton seeding in the local production district.

\section{Studied characters:}

Plants of five representative hills were taken at random from each plot at harvest to study the following traits:

A-Growth: plant height at harvest $(\mathrm{cm})$ and number of fruiting branches/ plant.

B-Earliness traits: number of total flowers/plant, number of total bolls/plant, boll setting percentage and boll shedding percentage.

C- Seed cotton yield and its components: number of open bolls per plant, boll weight ( $g$ ), lint percentage and seed index (weight of 100 cotton seeds in grams). The seed cotton yield per feddan was estimated as the weight of seed cotton in kilograms picked twice from each-sub plot and transformed to kentars per feddan (one kentar $=157.5$ kg)

Data were subjected to statistical analysis as proposed by Snedecor and Cochran (198.) and means were compared by LSD at $5 \%$ level of probability.

\section{RESULTS}

\section{A- Effect of the tested treatments} on growth traits:

Regarding the effect of the tested treatments on growth traits, the data in Table 3 show significant differences among the different treatments in both seasons. Untreated plants and plants which received $4 \mathrm{~g} / \mathrm{L}$ twice gave the tallest plants (160.87 and $158.17 \mathrm{~cm} ; 158.60$ and $157.10 \mathrm{~cm}$ ) with higher number of fruiting branches (16.25 and15.72; 15.12 and 15.50) in 2015 and 2016 seasons, respectively, while the shortest plants $(146.85$ and $145.30 \mathrm{~cm} ; 151.25$ and 150.60 $\mathrm{cm})$ were obtained from plants received $10 \mathrm{~g} / \mathrm{l}$ three times or two times in the first and second seasons, respectively, with lower number of fruiting branches.

\section{B-Effect of the tested treatments on earliness traits:}

In regard to the effect of foliar spraying with mixture of three organic acids(propionic, citric and ascorbic acids) and potassium citrate concentrations and number of applications on earliness traits, the results in Table 4 show that number of total bolls/plant and boll setting percentage significantly responded to concentrations and number of applications in favor of foliar spraying with $4 \mathrm{~g}$ of the mixture $/ /$ three times, where the mean values due to this treatment were 23.22 and $77.40 \% ; 22.80$ and $75.25 \%$ for number of total bolls/plant and boll setting percentage in the first and second seasons, respectively. However, the control (untreated plants) produced the lowest values, where the respective values were 20.33 and $67.16 \% ; 19.20$ and $63.79 \%$. 
Table (3): Effect of foliar spraying with mixture of three organic acids (propionic, Citric and ascorbic acids) and potassium citrate concentrations on cotton growth traits in 2016 and 2017 seasons.

\begin{tabular}{|l|c|c|c|c|}
\hline \multirow{2}{*}{ Traits } & \multicolumn{2}{|c|}{ Final plant height $(\mathrm{cm})$} & \multicolumn{2}{c|}{ No. of symposia/plant } \\
\cline { 2 - 5 } & Season 2016 & Season 2017 & Season 2016 & Season 2017 \\
\hline Control & 160.87 & 158.60 & 16.25 & 15.10 \\
\hline $4 \mathrm{~g} / /$ two times & 158.17 & 157.10 & 15.72 & 15.50 \\
\hline $4 \mathrm{~g} / /$ three times & 152.62 & 155.10 & 15.35 & 15.12 \\
\hline $8 \mathrm{~g} / /$ two times & 157.35 & 156.10 & 15.52 & 15.10 \\
\hline $8 \mathrm{~g} / /$ three times & 150.40 & 151.30 & 14.97 & 14.90 \\
\hline $10 \mathrm{~g} / /$ two times & 151.25 & 150.60 & 15.12 & 14.70 \\
\hline $10 \mathrm{~g} / /$ three times & 146.85 & 145.30 & 14.66 & 15.10 \\
\hline \multicolumn{1}{|c|}{ LSD at $5 \%$} & 4.38 & 3.50 & 0.48 & 0.61 \\
\hline
\end{tabular}

Table 4: Effect of foliar spraying with mixture of three organic acids (propionic, Citric and ascorbic acids) and potassium citrate concentrations on flowering traits in 2016 and 2017 seasons.

\begin{tabular}{|c|c|c|c|c|}
\hline$\underbrace{\text { Traits }}_{\text {Treatments }}$ & $\begin{array}{l}\text { No. of total } \\
\text { flowers/plant }\end{array}$ & $\begin{array}{l}\text { No. of total } \\
\text { bolls/ plant }\end{array}$ & Boll setting \% & Boll shedding $\%$ \\
\hline \multicolumn{5}{|c|}{ Season 2016} \\
\hline Control & 30.27 & 20.33 & 67.16 & 32.84 \\
\hline $4 \mathrm{~g} / /$ two times & 30.87 & 22.58 & 73.14 & 26.86 \\
\hline $4 \mathrm{~g} / /$ three times & 30.00 & 23.22 & 77.40 & 22.60 \\
\hline $8 \mathrm{~g} / \mathrm{l}$ two times & 29.65 & 22.18 & 74.81 & 25.19 \\
\hline $8 \mathrm{~g} / /$ three times & 29.87 & 22.50 & 75.33 & 24.67 \\
\hline $10 \mathrm{~g} / \mathrm{l}$ two times & 30.17 & 21.76 & 72.12 & 27.88 \\
\hline $10 \mathrm{~g} / /$ three times & 29.40 & 22.12 & 75.24 & 24.76 \\
\hline LSD at $5 \%$ & 1.20 & 0.87 & 1.60 & 1.60 \\
\hline \multicolumn{5}{|c|}{ Season 2017} \\
\hline Control & 30.10 & 19.20 & 63.79 & 36.21 \\
\hline $4 \mathrm{~g} / \mathrm{l}$ two times & 30.50 & 22.21 & 72.82 & 27.18 \\
\hline $4 \mathrm{~g} / /$ three times & 30.30 & 22.80 & 75.25 & 24.75 \\
\hline $8 \mathrm{~g} / \mathrm{l}$ two times & 29.20 & 21.90 & 75.00 & 25.00 \\
\hline $8 \mathrm{~g} / /$ three times & 29.70 & 22.30 & 75.08 & 24.92 \\
\hline $10 \mathrm{~g} / /$ two times & 30.00 & 22.00 & 73.33 & 26.67 \\
\hline $10 \mathrm{~g} / \mathrm{l}$ three times & 29.90 & 21.52 & 71.97 & 28.03 \\
\hline LSD at $5 \%$ & 1.15 & 0.78 & 1.41 & 1.41 \\
\hline
\end{tabular}


Regarding shedding \%, the differences among the tested treatments were significant in both seasons (Table 4). The highest values of shedding (32.84 and $36.21 \%$ ) were obtained from the control (untreated plants) in the first and second seasons, respectively. However, the lowest values of this trait were obtained by foliar spraying with $4 \mathrm{~g}$ of the mixture /I three times, where the respective values were 22.60 and $24.75 \%$. High temperature could lead to increase seeding of flower buds. boll retention is utmost desirable for higher values of harvests, while high temperature during this stage severely affects the boll retention as compared to any other factor.

\section{C-Effect of the tested treatments on cotton yield and yield components:}

The tested treatments gave significant effect on number of open bolls/plant, boll weight, seed index, lint $\%$ and seed cotton yield per feddan in both seasons (Table 5). Foliar feeding with $4 \mathrm{~g} / \mathrm{l}$ three times gave the highest number of open bolls/plant (23.22 and 22.80 boll), heavier bolls ( 3.25 and $3.30 \mathrm{~g}$ ), higher seed index $(11.08$ and $11.32 \mathrm{~g})$ and lint \% (42.80 and $43.07 \%$ ) in the first and second seasons, respectively. From the same Table it could be noticed that the differences between $4 \mathrm{~g} / \mathrm{l}$ and $8 \mathrm{~g} / \mathrm{l}$ three times were insignificant in both seasons. Results in the same Table show that, seed cotton yield per feddan was significantly affected by the tested treatments in both seasons, where the superiority was found in favor of foliar spraying with 4 or $8 \mathrm{~g}$ of the mixture/l three times as compared to the other treatments, where these two treatments significantly increased seed cotton yield per Fadden by 23.93 and 20.49\%; 29.49 and $\mathbf{2 7 . 3 1 \%}$ as compared with the control treatment in the first and second seasons, respectively. Heat stress at $40^{\circ} \mathrm{C}$ is reported to cause significant reductions in photosynthetic pigments, prolin contents and total soluble sugars along with decreased morphological attributes in two Egyptian cotton genotypes.

\section{DISCUSSION}

The positive response to the two concentrations ( 4 and $8 \mathrm{~g} / \mathrm{l}$ ) as foliar spraying three times with regard to traits under study might be due to the combined effect of each component in the mixture:

The role of potassium citrate and citric acid

1-The expected role of Potassium citrate in the mixture treatments in the balance of vegetative growth and increased the numbers of leaves and branches and accumulation of different plant growth substances in different organs of the plants.

2- Potassium is vital for plant growth because $K$ is known to be enzyme activator that promotes metabolism. Also, $\mathrm{K}$ promotes the translocation of photosynthates (sugars) for plant growth or storage in fruits or roots (Hearn, 1981).

3- The simulative effect due to the role of potassium on enzymes promotion activity and enhancing the translocation of assimilates and protein. Because $K$ is needed in photosynthesis and the synthesis of protein, plants lacking $K$ will have slow and stunted growth (Uchida, 2000). Potassium reduces boll shedding (Zeng, 1996). Potassium nutrition had pronounced effect on carbohydrates partitioning by affecting either phloem export of photosynthesis (sucrose) or growth rate of sink and/or sources organ (Cakmak et al., 1994). 
Table 5: Effect of foliar spraying with mixture of three organic acids (propionic, citric and ascorbic acids) and potassium citrate concentrations on cotton yield and its components in 2016 and 2017 seasons.

\begin{tabular}{|c|c|c|c|c|c|}
\hline$\underbrace{\text { Traits }}_{\text {Treatments }}$ & $\begin{array}{l}\text { No. of open } \\
\text { bolls/plant }\end{array}$ & $\begin{array}{c}\text { Boll } \\
\text { weight (g) }\end{array}$ & $\begin{array}{c}\text { Lint } \\
\%\end{array}$ & $\begin{array}{c}\text { Seed } \\
\text { index }(g)\end{array}$ & $\begin{array}{c}\text { Seed cotton } \\
\text { yield } \\
\text { (kantar/ fed) }\end{array}$ \\
\hline \multicolumn{6}{|c|}{ Season 2014} \\
\hline Control & 20.33 & 3.11 & 39.46 & 10.65 & 9.82 \\
\hline $4 \mathrm{~g} / /$ two times & 22.58 & 3.10 & 41.59 & 10.80 & 11.54 \\
\hline $4 \mathrm{~g} / /$ three times & 23.22 & 3.25 & 42.80 & 11.08 & 12.17 \\
\hline $8 \mathrm{~g} / /$ two times & 22.18 & 3.03 & 41.48 & 10.82 & 10.29 \\
\hline $8 \mathrm{~g} / /$ three times & 22.50 & 3.20 & 41.75 & 10.95 & 11.83 \\
\hline $10 \mathrm{~g} / \mathrm{t}$ two times & 21.76 & 3.10 & 40.15 & 10.60 & 11.10 \\
\hline $10 \mathrm{~g} / /$ three times & 22.12 & 3.08 & 40.85 & 10.70 & 10.39 \\
\hline LSD at $5 \%$ & 0.87 & 0.14 & 1.03 & 0.29 & 0.61 \\
\hline \multicolumn{6}{|c|}{ Season $201 \vee$} \\
\hline Control & 19.20 & 3.09 & 39.33 & 10.01 & 9.19 \\
\hline $4 \mathrm{~g} / /$ two times & 22.21 & 3.18 & 42.37 & 10.65 & 11.21 \\
\hline $4 \mathrm{~g} / /$ three times & 22.80 & 3.30 & 43.07 & 11.32 & 11.90 \\
\hline $8 \mathrm{~g} / \mathrm{l}$ two times & 21.90 & 3.00 & 41.18 & 10.45 & 10.30 \\
\hline $8 \mathrm{~g} / /$ three times & 22.30 & 3.20 & 42.53 & 10.73 & 11.70 \\
\hline $10 \mathrm{~g} / /$ two times & 22.00 & 3.10 & 40.30 & 10.20 & 10.90 \\
\hline $10 \mathrm{~g} / /$ three times & 21.52 & 3.05 & 40.96 & 10.30 & 10.15 \\
\hline LSD at $5 \%$ & 0.78 & 0.15 & 1.00 & 0.16 & 0.51 \\
\hline
\end{tabular}

4-Potassium affects respiration, photosynthesis, chlorophyll development, water content of leaves, carbon dioxide $\left(\mathrm{CO}_{2}\right)$ assimilation, and carbon movement (Sangakkara et al., 2000). Also, potassium, has an important role in the translocation of photosynthesis from sources (leaves) to sinks (bolls), (Cakmak et al., 1994). Potassium deficiencies can limit the accumulation of crop biomass. This has been attributed to a reduction in the partitioning of assimilates to the formation of leaf area and a decrease in the efficient use of intercepted radiation for the production of aboveground biomass.

5- Increases in the number of fruiting branches/plant, were accompanied with significant increase in each of bolls/plant, boll weight, seed cotton yield and seed index.

7- Fan et al., 1999, showed that the number of opened bolls per plant and boll weight, leading to higher cotton yield. Zeng (1996) indicated that K fertilizer reduced boll shedding. Potassium deficiencies can also limit the accumulation of crop biomass (Colomb et al., 1995). The present 
results could support the foundation of Fan et al. (1999) for maintaining the internal hormonal balance and providing an efficient sink-source relationship since, increasing the number of fruiting branches and bolls as well as boll weight are established effect of improving cytokines creation and that could be in the present of sufficient amount of potassium could be a direct and true reason for that significant increases in different yield characteristics.

V- Potassium citrate is potassium salt of citric acid which considered one of the most important organic acids in the respiratory pathways into plant cell (Ibrahim et al., 2015). Additionally, Citric acid $\left(\mathrm{C}_{3} \mathrm{H}_{5} \mathrm{O}(\mathrm{COOH})_{3}\right)$ plays an important role in plant metabolism, it's as nonenzymatic antioxidant in chelating free radicals and protecting plant from injury could result in prolonging the shelf life of plant cells and improving growth characters (Sadak and Orabi, 2015 and Wang et al., 2013).

$\lambda$-The enhancing effect of potassium on plant growth might be attributed to its association with the efficiency of leaf as an assimilator to $\mathrm{CO}_{2}$ (Rai et al., 2002), activating phyto-hormone, regulation of cellular $\mathrm{pH}$, enhancing $\mathrm{N}$ uptake, and acting as an activator to enzymatic systems (Marschner, 2012).

१-Citric Acid is an organic compound belonging to the family of carboxylic acids. It presents in practically all plants. It is one of a series of compounds involved in the physiological oxidation of fats, proteins and carbohydrates to $\mathrm{CO}_{2}$ and water.

\section{The role of ascorbic acid}

1-Ascorbic acid (AA) has beneficial impact on the plants under abiotic stress conditions. Ascorbic acid has an antioxidative role in plant scavenging the reactive oxygen species (ROS) and increasing yield of the crop.

2-Ascorbate is a major metabolite in plants performing a key role in plant protection against numerous environmental stresses like high temperature, salinity etc. (Shalata and Neumann, 2001; Vwioko et al., 2008). Heat stress, at squaring or flowering (as shown in Table 2), caused cell injury that badly impacted the cotton yield and its related components (as shown in Table 5). Foliar applied mixture containing ascorbic acid three times showed high productivity due to the considerable improvement in cell membrane thermostability and yield of heat-stressed cotton crop.

3-Ascorbic acid is used as an indication compound in many studies which are related with alleviation of stress (Lopez et al., 2011). Ascorbic acid is regarded as one of the most effective growth regulators in different abiotic stresses (Conklin, 2001) playing multiple roles in many developmental processes (Pignocchi and Foyer, 2003). Ascorbic acid, being an antioxidant, actively scavenges reactive oxygen species (ROS), reducing the chlorophyll degradation under salinity (Ashraf, 2009). It has ability to reduce the adverse impacts of stress on plants by neutralizing harmful oxidants which damage plant membranes such as thylakoid membranes of chloroplasts (Dolatabadian et al., 2009). Harmful oxidants which have been reported to damage plant membranes. In this regard, Kamal et al. (2017) reported that foliar application of ascorbic acid at $\mathbf{4 0}$ $\mathrm{mg} \mathrm{L}^{-1}$ reduced the cell injury and improved yield and related components under all heat treatments.

4-In the antioxidants system which involves antioxidant substances such as Ascorbic Acid which is a small water-soluble antioxidant molecule, that 
acts as a primary substrate in the cyclical pathway for detoxification and neutralization of superoxide radicals and singlet oxygen (Noctor and Foyer, 1998). Ascorbic acid (vitamin C) is one of the key products of D-glucose metabolism which synthesized in higher plants. It has been shown to play multiple roles in plant growth and development, such as cell division, cell wall expansion (Pignocchi and Foyer, 2003), the electron transport system (EIKobisy et al., 2005) and other developmental processes. The beneficial effects of ascorbic acid upon growth have been reported on cotton (Ghourab and Wahdan, 2000).

5- Khan et al. (2006) concluded that foliar spraying with ascorbic acid contributed in protection the photosynthetic machinery from the damaging effects of salt stress. Fercha et al. (2011) stated that the application of ascorbic acid mitigated the adverse effect of abiotic stress on plant growth which may be due, in part, to increased leaf area, improved chlorophyll and carotenoid contents and enhanced proline accumulation. He and Hader (2002) determined that ascorbic acid exhibited a protective influence on the lipid peroxidation under UV stress. Dolatabadian et al. (2009) reported that ascorbic acid, as an antioxidant, has the ability to mitigate the adverse impacts of stress on plants.

\section{The role of propionic or propanoic acid}

Propionic or propanoic acid (CH3CH2-COO-) is a weak monocarboxylic acid and an intermediate or end product of carbon metabolic pathways in pro- and eukaryotes (Schneider et al., 2011). Propionic acid is the second most abundant organic acid in soil (Conrad and Klose, 1999), therefore roots are constantly exposed to propionate and exogenous propionate naturally influences plant metabolism in the root.

\section{CONCLUSION}

It can be concluded that foliar spraying with three organic acids (propionic, citric and ascorbic acids) and potassium citrate in mixture(two portions potassium citrate, one portion propionic acid, one portion citric acid and one portion ascorbic acids) at a rate of $4 \mathrm{~g}$ of the mixture/l three times(during squaring stage, at the start of flowering and at the top of flowering) as anti-transpiration to improve cotton tolerance to high temperature during squaring and flowering stages and consequently increase productivity of cotton (Giza 86 variety), under the conditions of ElGemmeiza region.

\section{REFERENSES}

Abd-Allah, E.M., M.A. Issa, S.M. Abd ElKader, H.S. Abd EISalam and W.M. Abd ElHakim (2007). Effect of some antioxidants treatments on yield, some chemical constituents and antinutrional factors of some vegetable legumes. Proceedings of the 1st International Conference Desert Cultivation Problems and Solutions, March ( ${ }^{\top}$ ) 2007, Egypt.

Ashraf, M. (2009). Biotechnological approach of improving plant salt tolerance using antioxidants as markers. Biotechnol Adv. 27: 84-93.

Barth, C. and D. T. Mario (2006). The role of ascorbic acid in the control of flowering time and the onset of senescence. J. Exper. Botany 57: 1657-1665.

Cakmak, I. (2005). The role of potassium in alleviating detrimental effects of abiotic stresses in plants. J. Plant Nutr. Soil Sci., 168: 521- 530.

Cakmak, I., C. Hengeler and H. Marschner (1994). Partitioning of shoot and root dry weight and carbohydrates in bean 
plants suffering from phosphorus, potassium and magnesium deficiency. J., Exp. Bot., 45: 1245-1250.

Colomb, B., A. Bouniols and C. Delpech (1995). Effect of various phosphorus availabilities on radiation-use efficiency in sunflower biomass until anthesis. J. Plant Nutr. 18, 1649-1658.

Conklin, P.L. (2001). Recent advances in the role and biosynthesis of ascorbic acid in plants. Plant Cell Environ 24: 383-394.

Conklin, P.L. and C. Barth (2004). Ascorbic acid, a familiar small molecule intertwined in the response of plants to ozone, pathogens, and the onset of senescence. Plant Cell Env., 27, $959-971$.

Conrad, R. and M. Klose (1999). Anaerobic conversion of carbon dioxide to methane, acetate and propionate on washed rice roots. FEMS Microbiol. Ecol. 30: 147-155.

Dolatabadian A, S. A. Modarres and $M$. Sharifi (2009) Alleviation of water deficit stress effects by foliar application of Ascorbic Acid on Zea mays L. J of Agronomy and Crop Sci. 195:347-355

El-Kobisy, D. S., K. A. Kady, R. A. Medani and R. A. Agamy (2005). Response of pea plant (Pisum sativum L.) to treatment with ascorbic acid. Egypt $\mathrm{J}$ Appl Sci. 20:36-50.

Fan ShuLi, Xu YuZhang, Zhang ChaoJun (1999). Effects of nitrogen, phosphorus and potassium on the development of cotton bolls in summer. Acta Gossypii Sinica 11, 2430.

Farooq, M., A.B. Ali and A.C. Sardar (2013). Application of Allelopathy in Crop Production. Int J Agric and Biol 15: 1367-1378.

Fercha, A., H. Gherroucha and M. Baka (2011). Improvement of salt tolerance in durum wheat by vitamin $\mathrm{C}$ application. J. Stress Physiol Biochem 7: 27-37.

Ghourab, M.H.H. and G.A. Wahdan (2000). Response of cotton plants to foliar application of ascobine and ascorbic acid. Egypt J. Agric. Res., 78: 11951206.

Hearn (1981). plant physiology Sci., Book 10- 69.

He, Y.Y. and D.P. Hader (2002). UV-Binduced formation of reactive oxygen species and oxidative damage of the cyanobacterium Anabaena sp.: protective effects of ascorbic acid and $\mathrm{N}$-acetyl-Lcysteine. Journal of Photochemistry and Photobiology B: Biology 66: 115-124.

Jackson, M.L. (1973). Soil Chemical Analysis. Prentic-Hall, Inc, Englewood Cliffs, NJ, USA.

Kamal, M. A., M. F. Saleem, M. A. Wahid and A. Shakee (2017). Effects of ascorbic acid on membrane stability and yield of heat stressed Bt cotton. The J. Anim. Plant Sci. 27(1): 192-199.

Khan, A., M.S.A. Ahmad, H.R. Athar and M. Ashraf (2006). Interactive effect of foliar applied ascorbic acid and salt stress on wheat (Triticum aestivum L.) at seedling stage. Pak J Bot 39:14071414.

Khan, T. A., M. Mazi and F. Mohammad (2011). A review of ascorbic acid potentialities against oxidative stress induced in plants. J Agrobiol 28: 97111.

Lopez-Munguia, A., Y. HernandezRomero, J. Pedraza-Chaverri, A. Miranda-Molina, I. Regla, A. Martinez and E. Castillo (2011). Phenylpropanoid glycoside analogues: enzymatic synthesis, antioxidant activity and theoretical study of their free radical scavenger mechanism. PLoS One 6: 201-215.

Ibrahim, M. F. M., H. G. Abd El -Gawad and A. M. Bond (2015). Physiological Impacts of Potassium Citrate and 
Folic Acid on Growth, Yield and some Viral Diseases of Potato Plants. Middle East J. of Agric. Res. Vol. : 04 | Issue : 03 | July-Sept. | 2015 Pages: 577-589.

Marschner, P. (2012). Marschner's Mineral Nutrition of Higher Plants, 3rd ed.; Academic Press: London, UK, pp. 178-189.

Noctor, G. and C. H. Foyer (1998). Ascorbate and glutathione: keeping active oxygen under control. Ann Rev Plant Physiol Plant Mol Biol 49:249279.

Pavet, V., E. Olmos, G. Kiddle, S. Mowla, S. Kumar, J. Antoniw, M. E. Alvarez and C. H. Foyer (2005). Ascorbic acid deficiency activates cell death and disease resistance responses in Arabidopsis thaliana. Plant Physiol., 139: 1291-1303.

Pignocchi, C. and C.H. Foyer (2003). Apoplastic ascorbate metabolism and its role in the regulation of cell signalling. Curr. Opin. Plant Biol., 6: 379-389.

Rai, G.K., M.M. Verma and J. Singh (2002). Nitrogen and potassium interaction effect on yield attributes of potato. J. Indian Potato Association, 9(3-4): 153-154.

Sadak, M.S. and S.A. Orabi (2015). Improving thermo tolerance of wheat plant by foliar application of citric acid or oxalic acid. International Journal of Chem Tech Research, 8(1): 333-345.

Sangakkara, U.R., M. Frehner and J. Nosberger (2000). Effect of soil moisture and potassium fertilizer on shoot water potential, photosynthesis and partitioning of carbon in mungbean and cowpea. J. Agron. Crop Sci. 185: 201-207.

Schneider, K., M. Asao, M.S. Carter and B.E. Alber (2011). Rhodobacter sphaeroides Uses a Reductive Route via Propionyl Coenzyme A to
Assimilate 3-Hydroxypropionate. Journal of Bacteriology 194: 225-232.

Shalata, A. and P. M. Neumann (2001) Exogenous ascorbic acid increases resistance to salt stress and reduces lipid peroxidation. J Exp Bot. 52:22072211

Sheteawi, S.A. (2007). Improving growth and yield of salt-stressed soybean by exogenous application of jasmonic acid and ascobin. Int. J. Agric. Biol., 9: 473478.

Snedecor, G.W. and W.G. Cochran (1980). Statistical Methods. 6th Ed. lowa State Univ., U.S.A. pp: 225 - 269.

Uchida, R. (2000). Essential nutrients for plant growth: Nutrient functions and deficiency symptoms. Plant Nutrient Management in Hawaiis Soils. Approaches for tropical and Subtropical Agriculture. Chapter 3: 31 $-55$.

Vwioko, E.D., M.E. Osawaru, O.L. Eruogun (2008). Evaluation of okro (Abelmoschus esculentus L. Moench.) exposed to paint waste contaminated soil for growth, ascorbic acid and metal concentration. Afric J Gen Agric 4: 39-48.

Wang, M., Q. Zheng, Q. Shen and S. Guo (2013). The critical role of potassium in plant stress response. International Journal of Molecular Sciences 14(4): 7370-7390.

Wittwer, S. H. and F. G. Teubner (1959). Foliar absorption of mineral nutrients. Annu. Rev. Plant Physiol. 10: 13-27.

Zeng, Q. (1996). Experimental study on the efficiency of $\mathrm{K}$ fertilizer applied to cotton in areas with cinnamon soil or aquic soil. China Cottons, 23: 12.

Zhang, Y. (2012). Ascorbic Acid in Plants: Biosynthesis, Regulation and Enhancement. Dordrecht 
تأثير بعض المركبات العضوية على انتاجية القطن المصرى

يوبف فتحى أحمد عطا الله ، أمانى أحمد الاثثونى

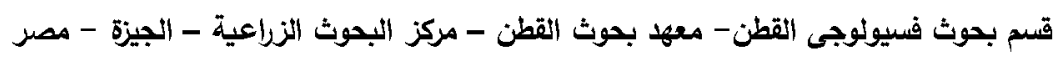

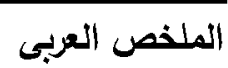

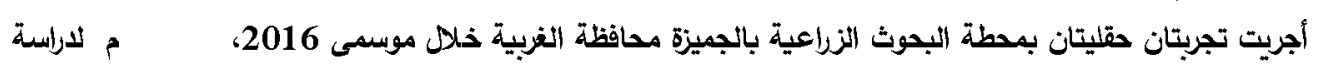

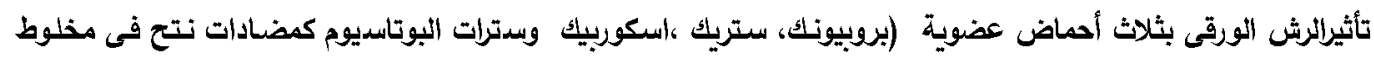

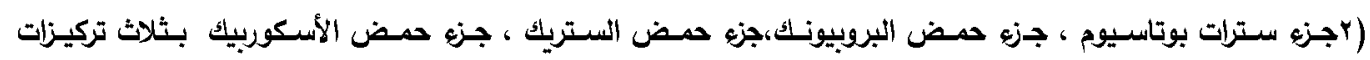

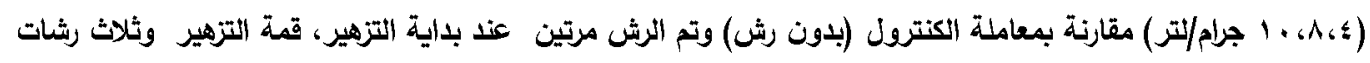

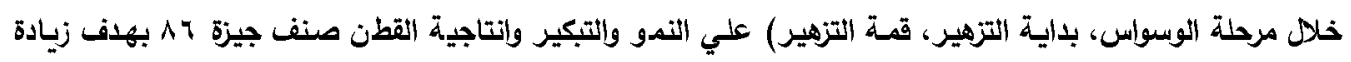

الأنتاجية وتم استخدم تصميم القطاعات الكاملة العشوائية في أربع مكربات.

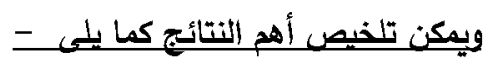

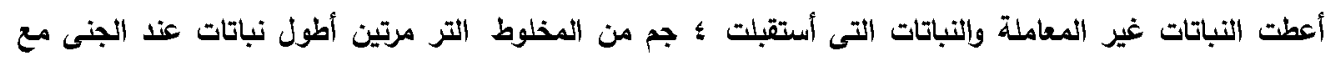

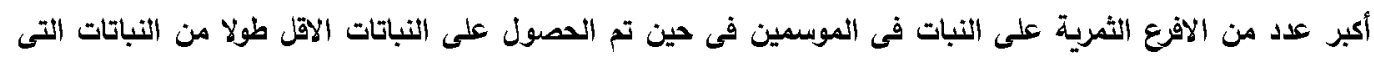

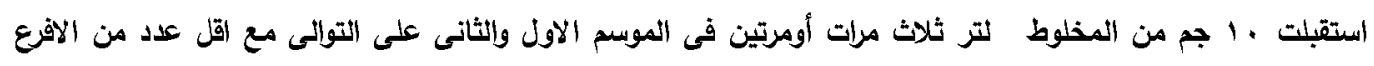
الثمرية .

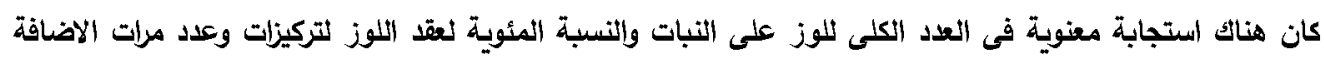

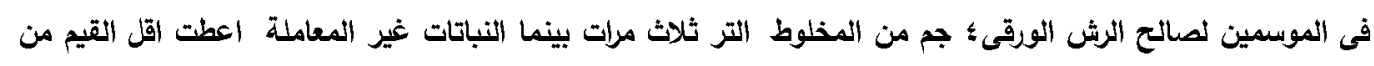

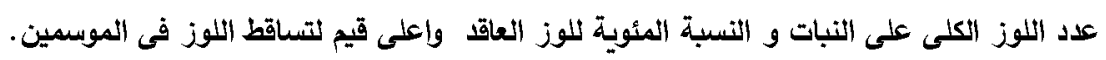

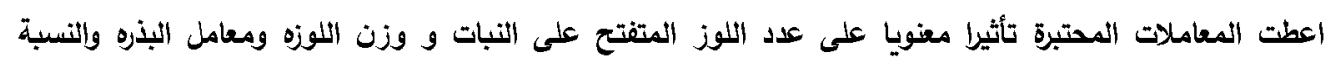

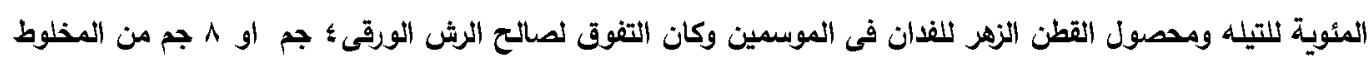

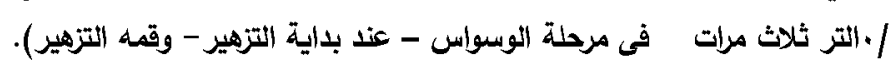
التوصية

يمكن التوصية بالرش الورقى بثلاث أحماض عضوية وسترات البوتاسيوم كمضادات نتح فى مخلوط اجزء سترات

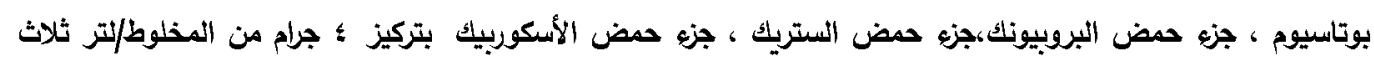

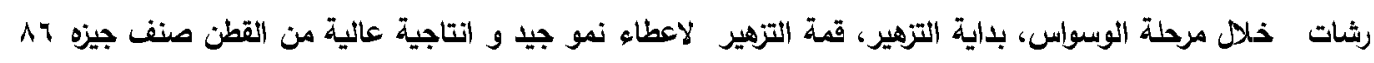

تصت ظروف منطقة الجميزة. 